\title{
Passionate about the Sport, Dedicated to the Club? A Systematic Review Study to the Predictors, Dimensions and Outcomes of Membership Involvement in Recreational Sports and Leisure
}

\author{
Nanny Kuijsters-Timmers ${ }^{1,2, *}$, John Goedee ${ }^{2,3}$, Roger Leenders ${ }^{3,4}$ \\ ${ }^{1}$ Department of Sports Marketing and Sports Communication (SPECO), Fontys University of Applied Sciences, Netherlands \\ ${ }^{2}$ Tilburg School of Humanities and Digital Sciences, Tilburg University, Netherlands \\ ${ }^{3}$ Tilburg School of Social and Behavioral Sciences, Tilburg University, Netherlands \\ ${ }^{4}$ Jheronimus Academy of Data Science, s-Hertogenbosch, Netherlands
}

Received September 19, 2019; Revised November 7, 2019; Accepted November 14, 2019

Copyright $(2019$ by authors, all rights reserved. Authors agree that this article remains permanently open access under the terms of the Creative Commons Attribution License 4.0 International License

\begin{abstract}
Aspects of involvement in sports and active leisure in an organized context have been extensively investigated, but none of these studies provides a comprehensive picture of the membership involvement of members in voluntary clubs (MI). Our research aims to obtain an overview of existing knowledge on MI by conducting a systematic review study of academic articles. The results show that, over the years, insights into MI have increased, inducing a well-elaborated concept. MI appears to be shaped by three main dimensions (i.e., participation, personal relevance, social world), four groups of predictors (i.e., personal characteristics, psychological, organizational, and social aspects) and three levels of outcomes, for individuals (i.e. health, skills, diversion, social connectedness), organizations (i.e., support and loyalty) and society (i.e., healthy life style, social capital, learning communities). Moreover, we show a circular effect of the outcome-aspects that also predict MI. Based on these results, we develop a framework of membership involvement, propose future research directions, and discuss scientific and practical implications.
\end{abstract}

Keywords Involvement, Membership, Voluntary Club, Leisure, Recreational Sports, Systematic Review

\section{Introduction}

Members are the most important stakeholders in voluntary sports and active leisure clubs (hereafter 'voluntary clubs'). Therefore, it is important to understand the attachment of members to a club. In this article, we define this concept as membership involvement (MI) Understanding membership involvement of members enhances our insights in perceptions and motives of members regarding their attachment to member organizations. More practically, these insights can help to mitigate the trend of decreasing membership that the voluntary clubs are facing, especially in Europe (Borgers et al., 2018a; Breuer et al., 2016). This decreasing membership has negative consequences for organizational effectiveness, such as a lower inflow of membership fees and fewer volunteers to perform club-related tasks (Sotiriadou et al., 2014; Thiel and Mayer, 2008; Van der Roest et al., 2016).

With this article, we aim to understand the concept of membership involvement by identifying aspects that comprehensively capture the dimensions of MI and its predictors and outcomes.

\subsection{Involvement of Members in Recreational Sport and Active Leisure}

Generally, involvement in organizations refers to the attachment of members to their organizations, based on emotions, cognitions, and experiences (Etzioni, 1980; Hallberg and Schaufeli, 2006; Penley and Gould, 1988). High involvement motivates members to support the organization, but low involvement stimulates alienation (Etzioni, 1980; Penley and Gould, 1988). In sport and active leisure activities - such as outdoor activities or dancing - involvement is also assumed to be a prerequisite for obtaining support and loyalty. For example, Havitz and Dimanche (1999) described involvement as an arousal or interest towards an activity that is a key factor for the 
duration of participation. In the context of voluntary clubs, the interest of members in specific activities was also found to influence the decision to actively engage in voluntary tasks (Schlesinger and Nagel, 2011; Van der Roest et al., 2016) and the effort and performance of volunteer commitment (Engelberg et al., 2011).

Furthermore, involvement has been linked to concepts such as 'sense of community' (Kellett and Warner, 2011; Warner et al., 2012), 'social capital,' (Nielsen et al., 2012; Seippel, 2006; Vandermeerschen et al., 2016) and the 'social worlds' that members create within voluntary clubs (Gahwiler and Havitz, 1998; Wood and Danylchuk, 2011). These concepts mainly explain the cohesion and solidarity based on the social networks among participants in sports and active leisure and are found to be indicators of members' willingness to support the voluntary clubs' objectives (Schlesinger and Nagel, 2015; Van der Roest et al., 2017). Thus, concepts such as sense of community, social capital and social world, refer more to relations between members in organized or non-organized contexts, such as in a neighborhood, than that they specifically clarify members' attachment to the organization (Gahwiler and Havitz, 1998; Warner et al., 2012). Over the years, many articles have been published on involvement in recreational sports and leisure, but we do not know of any article that has tapped into the definition of "membership involvement" as the specific attachment of members to their voluntary clubs. This is what we investigate in the current study. We aim to provide a definition of the concept of MI of members in voluntary clubs, based on a synthesis of indicators in scholarly research of the involvement and membership in the field of recreational sports and active leisure.

There are several reasons to provide this definition of MI. In many European countries, a large part of the population participates in sports or active leisure through membership of a voluntary club (Breuer et al., 2016; European Commission, 2014). Historically, membership of the voluntary clubs has cultural, social, political, and even religion roots; for decades membership was dictated by a person's background (such as one's religious affiliation, social status, or young age), rather than being an individual choice (Breuer et al., 2016; Waardenburg \& Van Bottenburg, 2013). However, changes in society, such as growing individualism and living a healthy lifestyle, have increasingly affected people's motivation to become and remain a member of voluntary sports clubs. As an example, as society started to increasingly value a healthy lifestyle, commercial sports companies, such as fitness centers, have successfully entered the market and started to attract athletes of all ages (Breuer et al., 2016; Van Bottenburg et al., 2005; Van der Roest et al., 2016). As a result, membership of voluntary clubs has become more age-diverse than ever before (Geidne et al., 2013; Van Bottenburg et al., 2005; Waardenburg, 2016).

Within voluntary clubs, members are both producers and recipients of the service and pay an annual fee for it, which stimulates an emotional attachment to their clubs (Thiel and Mayer, 2008; Van der Roest et al., 2016). It seems obvious that it is primarily the members with emotional attachment who spend a large part of their free time in the club (Borgers et al., 2016), partake in voluntary work, are active in the democratic decision making (Emrich et al., 2014; Thiel and Mayer, 2008; Van der Roest et al., 2016), and form social networks of relatives, peers, and friends (Schlesinger and Nagel, 2015; Warner et al., 2012). This attachment of members to their club captures the concept of 'membership involvement' and in the current study, we identify the indicators of this concept, its predictors, and its outcomes. Furthermore, previous research has linked membership in voluntary clubs to individual and societal outcomes, such as a healthy lifestyle (Eime et al., 2010; Geidne et al., 2013), with enduring participation in sports (Borgers et al., 2018b), social connectedness (Nielsen et al., 2012; Seippel, 2006), and social cohesion (Darcy et al., 2014; Putnam, 2001). Moreover, some of these outcomes, such as being socially connected with others, also correspond to reasons to join a club (Borgers et al., 2016; Van der Roest et al., 2017; Seippel, 2006), and thereby suggests a circular effect. In this research, we explore this circular process and the role of membership involvement in it.

Although involvement in sports and membership of voluntary clubs have been studied extensively, there is no clear and comprehensive overview of the dimensions, predictors, and outcomes of membership involvement of voluntary clubs. Hence, we conducted a thematic analysis, by which we identify and synthesize indicators of the concept of MI of members (Dixon-Woods et al., 2005; Weed, 2005). Subsequently, we present our results in a 'framework of membership involvement of members in voluntary sports and active leisure clubs,' which gives an overview of our knowledge in this field.

\section{Method}

\subsection{Systematic Review and Thematic Analysis}

Following the PRISMA guidelines for systematic reviews (Moher et al., 2009) we selected relevant studies from the extensive literature on recreational sports and active leisure activities. Although not frequently applied in social research, systematic reviews allow us to synthesize findings from the literature in an organized and structured, transparent, and reproducible manner, allowing researchers to enhance a knowledge base reliably (Moher et al., 2009; Tranfield et al., 2003; Weed, 2005). Furthermore, a literature synthesis yields a comprehensible overview when existing studies are not consistent, contain contradictory information, or do not clearly interpret definitions and concepts (Stansfield et al., 2016; Weed, 2005). 


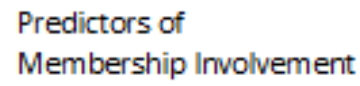

Dimensions of Membership Involvement
Outcomes of

Membership Involvement

Figure 1. The conceptual model of membership involvement of members

In this study, we used thematic analysis to identify indicators of dimensions, predictors, and outcomes of the concept of MI, and indicators of the circular effect (see the conceptual model in Figure 1). Thematic analysis is an interpretative method that allows the researcher to identify and combine the main, recurrent, or most important issues or themes - shaped by the specific review questions - and to approach the literature under these themes (Dixon-Woods et al., 2005; Tranfield et al., 2003).

\subsection{Literature Search and Review Procedure Based on the PRISMA Guidelines}

Based on the PRISMA guidelines (Moher et al., 2009), we conducted a systematic search (see Figure 2) using the Ebscohost (SportDiscuss and Psycharticles) and ProQuest (Social Sciences) engines. We searched for works published from 1980 through August 2018, a time frame that marks the shift to a more individual choice for membership (Breuer et al., 2016; Van Bottenburg et al., 2005; Van der Roest et al., 2016). We combined the terms 'involvement,' 'sports, 'leisure,' 'member,' 'membership, 'voluntary sports club,' 'association,' and 'sports club' in the title and key words. We selected only academic articles and added two articles from other sources. In total, 977 peer-reviewed articles were identified. To ensure selecting only the relevant literature, we evaluated and screened the titles and abstracts according to our review selection criteria. Furthermore, we examined whether the articles refer to active participation in sports or leisure activities at a club, such as a fitness club, leisure club, or voluntary sports club. We only included articles on the subject of leisure when they referred to physical activity. A set of 104 articles were obtained, and, by screening the full text of the articles, we excluded 79 articles that did not convincingly refer to active participation in sports and leisure.

To be included as relevant in our final review, a source must have (1) examined aspects of involvement in the context of recreational sports or physical leisure club or program, (2) used a sample of people who were participants in sports or leisure activities or active as board members or volunteers at their sports or leisure club, (3) been published in a peer-reviewed academic journal, and (4) reported empirical findings. The selection led to a total of 25 articles that met the requirements (see Table 1 for an overview). The selected articles contain studies that examined involvement in organized and non-organized recreational sports and leisure settings, for example intramural sports, fitness clubs, voluntary and community sports clubs, organized school, and student sports clubs.

Furthermore, in the articles, types of involvement in the context of sports and leisure were presented, such as sport involvement, leisure involvement, athletic involvement, task involvement, and activity involvement. The methodology used in these studies included survey studies (20), mixed method studies - a survey \& in-depth interview study (1), and an in-depth interview \& narrative study (1) a case study (1), an experiment (1), and an in-depth interview study (1). For each selected article, we show the key information in Table 1. We assessed this body of articles according to the thematic analysis procedure for interpretative syntheses (Dixon-Woods et al., 2005; Tranfield et al, 2003) and by applying our conceptual model of membership involvement (see Figure 1). In doing so, we identified the dimensions, predictors, outcomes, and aspects of membership that are related to involvement. 

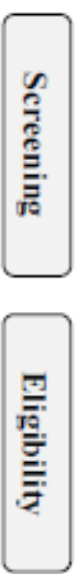

흘
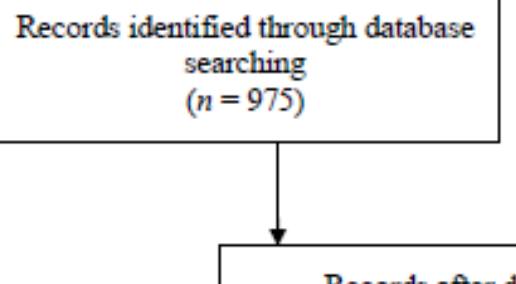

Records after duplicates removed $(n=977)$
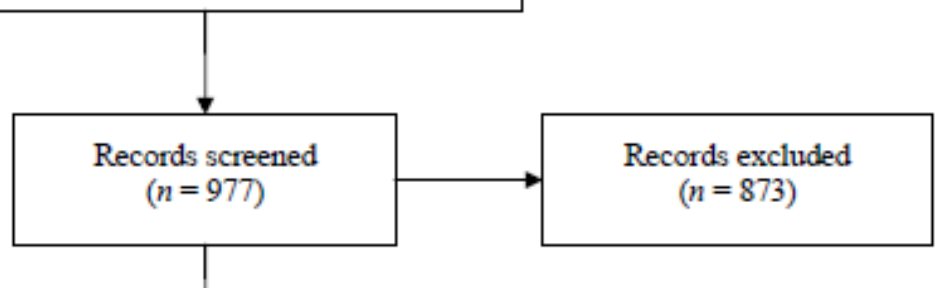

Full-text articles assessed for eligibility $(n=104)$

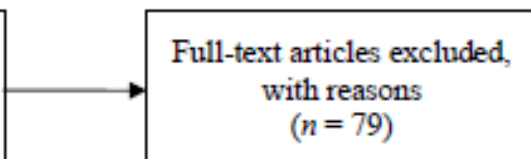

Studies included in qualitative synthesis $(n=25)$

Figure 2. Search procedure for the systematic review. 
Table 1. Overview of the articles used in the thematic analyses

\begin{tabular}{|c|c|c|c|c|c|c|}
\hline Article & Author(s) & $\begin{array}{l}\text { Context and } \\
\text { country* }\end{array}$ & Sample and age & Aspect(s) or independent variable(s) & Dependent variable(s) & Main results \\
\hline 1 & Sack, 1988 & $\begin{array}{c}\text { VSC \& } \\
\text { non-club; GER }\end{array}$ & $\begin{array}{l}\quad n=666 \\
\text { Age range } 12 \text { to } 18\end{array}$ & $\begin{array}{l}\text { Group styles in youth culture (12 types } \\
\text { of styles, i.e., football fans, punks, disco } \\
\text { fans, ecologists, etc.) }\end{array}$ & $\begin{array}{c}\text { Member of a sports club; active in } \\
\text { sports }\end{array}$ & $\begin{array}{l}\text { Stability of involvement; positive relation of } \\
\text { involvement with sport or sport situation specific } \\
\text { characteristics of the lifestyle; preference and } \\
\text { social background are influencers for being active } \\
\text { in sport }\end{array}$ \\
\hline 2 & $\begin{array}{l}\text { Rudman, } \\
1989\end{array}$ & SP; USA & $\begin{array}{l}n=968 \\
\text { Age range } \\
<34 \text { to }>50\end{array}$ & $\begin{array}{l}\text { Barriers: motivation, time, limiting } \\
\text { health, excuses, and lack of energy - } \\
\text { benefits: psychological, body/image } \\
\text { health, competition, and family fun }\end{array}$ & Membership in sports programs & $\begin{array}{l}\text { Ageing is related to involvement; perceived } \\
\text { psychological benefits are the most powerful } \\
\text { predictors }\end{array}$ \\
\hline 3 & $\begin{array}{c}\text { Shank and } \\
\text { Beasley, } 1998\end{array}$ & $\begin{array}{l}\text { VSC \& NM; } \\
\text { USA }\end{array}$ & $\begin{array}{c}n=136 \\
\text { Mage }=39.35\end{array}$ & $\begin{array}{l}\text { Sports involvement (cognitive, } \\
\text { affective), media habits, and } \\
\text { participation in sports }\end{array}$ & Participating in sports, media habits & $\begin{array}{l}\text { Sports involvement predicts sports-related } \\
\text { behavior }\end{array}$ \\
\hline 4 & $\begin{array}{l}\text { Wiley et al., } \\
2000\end{array}$ & VSC; Canada & $\begin{array}{c}n=205 \\
\text { Mage }=37.4\end{array}$ & $\begin{array}{l}\text { Activity (hockey and figure skating), } \\
\text { gender, age, gender-role, frequency, and } \\
\text { duration }\end{array}$ & $\begin{array}{c}\text { Sport involvement; sport activity } \\
\text { involvement }\end{array}$ & $\begin{array}{l}\text { Frequency, duration predicted involvement, and } \\
\text { involvement varies by gender }\end{array}$ \\
\hline 5 & $\begin{array}{l}\text { Kyle and } \\
\text { Chick, } 2004\end{array}$ & Leisure; USA & $\begin{array}{l}\quad n=19 \\
\text { Age range } 51 \text { to } 87\end{array}$ & $\begin{array}{c}\text { Experiences that sustained involvement } \\
\text { with the activity }\end{array}$ & (Enduring) leisure involvement & $\begin{array}{l}\text { Relationships with family and friends were most } \\
\text { important }\end{array}$ \\
\hline 6 & $\begin{array}{l}\text { Havitz and } \\
\text { Manell, } 2005\end{array}$ & $\begin{array}{l}\text { Leisure; } \\
\text { Canada }\end{array}$ & $\begin{array}{l}\quad n=46 \\
\text { Age range } 20 \text { to } 60\end{array}$ & $\begin{array}{l}\text { Enduring involvement (EI) and } \\
\text { situational involvement (SI) }\end{array}$ & Flow & $\begin{array}{l}\text { Relationships between El, SI, and flow; SI } \\
\text { mediated the El-flow relationship, with no direct } \\
\text { paths between El and flow }\end{array}$ \\
\hline 7 & $\begin{array}{l}\text { Kyle et al., } \\
\quad 2006\end{array}$ & $\begin{array}{c}\text { Leisure } \\
\text { outdoor; USA }\end{array}$ & $\begin{array}{c}n=424 \\
\text { Mage }=39.35\end{array}$ & $\begin{array}{l}\text { Motivation: escape, nature, bonding, } \\
\text { learning, and social }\end{array}$ & $\begin{array}{l}\text { Enduring involvement (attraction, } \\
\text { centrality, social bonding, identity } \\
\text { affirmation, and identity } \\
\text { expression) }\end{array}$ & $\begin{array}{l}\text { Dimensions of motivation positively influence the } \\
\text { dimensions of enduring involvement }\end{array}$ \\
\hline 8 & $\begin{array}{l}\text { Rockafellow } \\
\text { and Saules, } \\
2006\end{array}$ & $\begin{array}{l}\text { SSC \& VSC; } \\
\quad \text { USA }\end{array}$ & $\begin{array}{l}\quad n=218 \\
\text { Age range } 18 \text { to } 24\end{array}$ & $\begin{array}{l}\text { Athletic involvement (participation in } \\
\text { intercollegiate athletics, intramural } \\
\text { sports, club sports, exercise, forms of } \\
\text { physical activity, and amount of time); } \\
\text { situational motivation; substance use }\end{array}$ & Substance use & $\begin{array}{l}\text { Athletic involvement is related to substance use; } \\
\text { extrinsically motivated athletes and exercisers are } \\
\text { more strongly related to substance use than others }\end{array}$ \\
\hline 9 & $\begin{array}{l}\text { Spray et al., } \\
\quad 2006\end{array}$ & $\begin{array}{l}\text { Golf putting } \\
\text { task; UK }\end{array}$ & $\begin{array}{c}n=147 \\
\text { Mage }=13.43\end{array}$ & $\begin{array}{l}\text { Goal involvement: task involvement } \\
\text { (focus on skills) and ego involvement } \\
\text { (focus on competition); communication } \\
\text { styles: autonomous and controlling }\end{array}$ & Task performance & $\begin{array}{l}\text { Better performance in task involved condition; } \\
\text { greater enjoyment, longer persistence at the task, } \\
\text { and better performance in autonomous conditions }\end{array}$ \\
\hline 10 & Hoye, 2007 & $\begin{array}{l}\text { VSC (Race); } \\
\text { Australia }\end{array}$ & $\begin{array}{l}\quad n=159 \\
\text { Age median 50-59 }\end{array}$ & $\begin{array}{l}\text { Involvement (effort and participation) } \\
\text { and affective commitment }\end{array}$ & $\begin{array}{l}\text { Board member performance } \\
\text { (self-registered) }\end{array}$ & $\begin{array}{c}\text { Affective commitment and the involvement aspect } \\
\text { 'effort' predicted perceived board member } \\
\text { performance }\end{array}$ \\
\hline
\end{tabular}


Passionate about the Sport, Dedicated to the Club? A Systematic Review Study to the Predictors, Dimensions and Outcomes of Membership Involvement in Recreational Sports and Leisure

\begin{tabular}{|c|c|c|c|c|c|c|}
\hline 11 & $\begin{array}{l}\text { Alexandris et } \\
\text { al., } 2008\end{array}$ & $\begin{array}{c}\text { Leisure } \\
\text { (Skiing); } \\
\text { Greece }\end{array}$ & $\begin{array}{c}n=190 \\
\text { Age range } \\
18 \text { to }>46\end{array}$ & $\begin{array}{l}\text { Leisure involvement: centrality, } \\
\text { attraction, and self-expression; leisure } \\
\text { constraints: skiing experience, } \\
\text { psychological constraints, time, } \\
\text { finance/accessibility, and lack of } \\
\text { partners }\end{array}$ & Leisure involvement, Skiing loyalty & $\begin{array}{c}\text { Attraction and centrality predicted skiing loyalty; } \\
\text { psychological and time-related constraints } \\
\text { predicted leisure involvement }\end{array}$ \\
\hline 12 & $\begin{array}{l}\text { Mullen and } \\
\text { Whaley, } 2010\end{array}$ & $\begin{array}{l}\text { CSC (Fitness); } \\
\text { USA }\end{array}$ & $\begin{array}{l}n=326 \\
\text { Age range } \\
25 \text { to }>55\end{array}$ & $\begin{array}{l}\text { Physical activity levels, reasons for } \\
\text { participation, factors facilitating } \\
\text { commitment (physical changes and } \\
\text { feeling in control), and qualities of a } \\
\text { fitness facility }\end{array}$ & Initial involvement & $\begin{array}{c}\text { Age and gender factors facilitating commitment } \\
\text { and qualities of a fitness facility }\end{array}$ \\
\hline 13 & $\begin{array}{l}\text { Beaton et al., } \\
\quad 2011\end{array}$ & $\begin{array}{l}\mathrm{NM} \\
\text { (Marathon); } \\
\text { USA }\end{array}$ & $n=3,117$ & $\begin{array}{c}\text { Sport involvement: hedonic value } \\
\text { (enjoyment), centrality, symbolic value } \\
\text { (self-expression value), number of } \\
\text { running events, and member of a running } \\
\text { club }\end{array}$ & Stages of activity engagement & $\begin{array}{l}\text { Sport involvement associated with stages of PCM; } \\
\text { differences for belonging to a running club by stage } \\
\text { of PCM }\end{array}$ \\
\hline 14 & $\begin{array}{l}\text { Alexandris, } \\
2012\end{array}$ & $\begin{array}{l}\text { VSC (Tennis); } \\
\text { Greece }\end{array}$ & $\begin{array}{l}\quad n=200 \\
\text { Age range } 18>65\end{array}$ & $\begin{array}{l}\text { Frequency of participation; motivation: } \\
\text { intrinsic, extrinsic, and amotivation }\end{array}$ & Sport involvement & $\begin{array}{l}\text { Sport involvement related to frequency of } \\
\text { participation; intrinsic and extrinsic motivation } \\
\text { predicted centrality; amotivation predicted } \\
\text { attraction }\end{array}$ \\
\hline 15 & $\begin{array}{l}\text { Alexandris et } \\
\text { la., } 2012\end{array}$ & $\begin{array}{l}\text { VSC (dancing): } \\
\text { Greece }\end{array}$ & $\begin{array}{l}\quad n=140 \\
\text { Age not mentioned }\end{array}$ & $\begin{array}{l}\text { Leisure involvement: centrality, } \\
\text { attraction, and self-expression; service } \\
\text { quality scale: tangibles, personnel, } \\
\text { responsiveness, reliability, and outcome }\end{array}$ & High and low leisure involvement & $\begin{array}{l}\text { Important to leisure involvement: tangibles, } \\
\text { responsiveness, reliability, and outcome; } \\
\text { interaction is motive for involvement }\end{array}$ \\
\hline 16 & $\begin{array}{l}\text { Ridinger et } \\
\text { al., } 2012\end{array}$ & $\begin{array}{l}\text { NM (Running); } \\
\text { World }\end{array}$ & $\begin{array}{l}\quad n=1,190 \\
\text { Age range } 30 \text { to } 49\end{array}$ & $\begin{array}{l}\text { Leisure involvement aspects: pleasure, } \\
\text { centrality, self-expression, and } \\
\text { negotiation efficacy }\end{array}$ & Commitment & $\begin{array}{c}\text { Relationship between running commitment and } \\
\text { pleasure and centrality; medium relationship } \\
\text { between negotiation-efficacy and running } \\
\text { commitment }\end{array}$ \\
\hline 17 & $\begin{array}{l}\text { Alexandris, } \\
2013\end{array}$ & $\begin{array}{l}\text { VSC (Tennis); } \\
\text { Greece }\end{array}$ & $\begin{array}{l}\quad n=200 \\
\text { Age range } 18>65\end{array}$ & $\begin{array}{c}\text { Constraints (time, individual } \\
\text { psychological, knowledge, } \\
\text { facilities/services, accessibility/costs, } \\
\text { and partners); motivation (intrinsic, } \\
\text { extrinsic, and amotivation) }\end{array}$ & $\begin{array}{l}\text { High and low leisure involvement } \\
\text { (attraction, centrality, } \\
\text { self-expression, social bonding }\end{array}$ & $\begin{array}{l}\text { High involvement: (high) extrinsic and intrinsic } \\
\text { motivation, (low) amotivation; low involvement: } \\
\text { (high) individual psychological, lack of time and } \\
\text { facilities/services }\end{array}$ \\
\hline 18 & Kuo, 2013 & VSC; Taiwan & $\begin{array}{l}n=516 \\
\text { Age range } \\
<20 \text { to }>51\end{array}$ & $\begin{array}{c}\text { Involvement in recreational sport } \\
\text { (leisure attraction, centrality of life, and } \\
\text { impact of friends); work stress and } \\
\text { leisure sport coping strategies; quality of } \\
\text { life } \\
\end{array}$ & Sport commitment & $\begin{array}{l}\text { Positive impact of recreational sport involvement } \\
\text { on leisure sport coping strategies; quality of life } \\
\text { influenced sport commitment positively }\end{array}$ \\
\hline 19 & $\begin{array}{l}\text { Ringuet-Riot } \\
\text { et al., } 2013\end{array}$ & CSC; Australia & $\begin{array}{c}n=243 \\
\text { Mage }=43.2\end{array}$ & $\begin{array}{l}\text { Volunteer involvement (in primary role } \\
\text { and in club), commitment to volunteer } \\
\text { role and club, contribution to } \\
\text { decision-making, contribution to } \\
\text { planning, and practical work }\end{array}$ & Core and peripheral volunteers & $\begin{array}{l}\text { Volunteer involvement roles are important; core } \\
\text { volunteers tended to be more highly involved and } \\
\text { committed }\end{array}$ \\
\hline
\end{tabular}




\begin{tabular}{|c|c|c|c|c|c|c|}
\hline 20 & $\begin{array}{l}\text { Adachi and } \\
\text { Willoughby, } \\
2014\end{array}$ & $\begin{array}{l}\text { SSC \& VSC; } \\
\quad \text { Canada }\end{array}$ & $\begin{array}{c}n=1,492 \\
\text { Mage }=13.10\end{array}$ & $\begin{array}{l}\text { Sport involvement: frequency of playing } \\
\text { organized sports in and outside of } \\
\text { school; video game playing; self esteem }\end{array}$ & Involvement in sports & $\begin{array}{l}\text { Long-term bidirectional association between sports } \\
\text { video game play and involvement in sports; } \\
\text { self-esteem mediates sports video game play in } \\
\text { predicting involvement in sports }\end{array}$ \\
\hline 21 & $\begin{array}{l}\text { Hoye et al., } \\
\quad 2015\end{array}$ & $\begin{array}{l}\text { Diverse sports; } \\
\text { CSC; Australia }\end{array}$ & $\begin{array}{l}\quad n=1,548 \\
(\text { convenience }) \\
\text { Age range } 20 \text { to }>76\end{array}$ & $\begin{array}{c}\text { Involvement in community sport } \\
\text { organizations, no involvement, and other } \\
\text { forms of involvement in associational } \\
\text { life }\end{array}$ & Social connectedness & $\begin{array}{l}\text { Involvement in community sport predicted social } \\
\text { connectedness; involvement in non-sport } \\
\text { community organizations not associated with } \\
\text { social connectedness. }\end{array}$ \\
\hline 22 & $\begin{array}{l}\text { Wood and } \\
\text { Danylchuk, } \\
2015\end{array}$ & SSC; Canada & $\begin{array}{c}n=237 \\
\text { Mage }=19.6\end{array}$ & $\begin{array}{c}\text { Constraints (intrapersonal, interpersonal, } \\
\text { and structural), negotiation strategies } \\
\text { (time management, skill acquisition, and } \\
\text { interpersonal coordination) }\end{array}$ & Involvement in intramural sports & $\begin{array}{l}\text { Constraints and negotiation strategies both } \\
\text { predicted involvement in intramural sports }\end{array}$ \\
\hline 23 & $\begin{array}{l}\text { Flosdorf et } \\
\text { al., } 2016\end{array}$ & SSC; USA & $\begin{array}{l}\quad n=11 \\
\text { age range } 18 \text { to } 22, \\
\text { Mage }=21\end{array}$ & $\begin{array}{l}\text { Social, vocational and practical } \\
\text { competence, involvement (physical: } \\
\text { time investment frequency/attending } \\
\text { activities; administrative activities; and } \\
\text { psychological: fun, stress, importance, } \\
\text { challenge, and educational) }\end{array}$ & $\begin{array}{c}\text { Personal development through } \\
\text { student involvement in a sports club }\end{array}$ & $\begin{array}{l}\text { Student involvement related to psychosocial and } \\
\text { physical energy; involvement is connected to } \\
\text { development; academic performance is related to } \\
\text { involvement. }\end{array}$ \\
\hline 24 & $\begin{array}{l}\text { Forrester et } \\
\text { al., } 2017\end{array}$ & SSC, Canada & $\begin{array}{l}\text { Undergraduates }(n= \\
3,257) ; \text { staff }(n=35) ; \\
\text { officials }(n=24) ; \\
\text { participants }(\mathrm{n}=461)\end{array}$ & $\begin{array}{l}\text { CRS involvement (through employment, } \\
\text { through intramural participation) general } \\
\text { student entering year } 1,2 \text { or } 3\end{array}$ & Retention rates of students & $\begin{array}{l}\text { Students involved in CRS (employment or } \\
\text { intramural participant) showed significantly higher } \\
\text { year two, three, and four retention rates when } \\
\text { compared to the broader undergraduate student } \\
\text { population at the university. }\end{array}$ \\
\hline 25 & $\begin{array}{l}\text { Dobersek and } \\
\text { Arellano, } \\
2017\end{array}$ & SSC, USA & $\begin{array}{l}\quad n=203 ; \\
\text { age range } 18 \text { to } 52 \\
\text { (Mage 21.42) }\end{array}$ & $\begin{array}{l}\text { Emotional intelligence (empathy, } \\
\text { utilization of feelings, handling } \\
\text { relationships, self-control), involvement } \\
\text { in collegiate sports }\end{array}$ & $\begin{array}{l}\text { Academic achievements (grade } \\
\text { point average, GPA) }\end{array}$ & $\begin{array}{l}\text { Student-athletes demonstrated higher GPA; } \\
\text { non-athletes scored higher on EI than } \\
\text { student-athletes }\end{array}$ \\
\hline
\end{tabular}

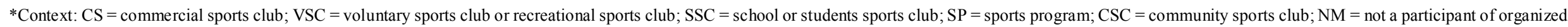
sports. 


\section{Results}

The results of our thematic analysis reveal indicators that together depict membership involvement as a mediating concept, consisting of three dimensions, four groups of predictors, and outcomes on three levels (see Figure 3 and Table 2). The main results presented in the framework for MI of members in voluntary sports and active leisure clubs (Table 2) are discussed with the numbers in brackets corresponding to the numbering of the articles in the overview (Table 1).

\section{Predictors of}

membership involvement:

1. Personal characteristics

2. Psychological aspects

3. Organizational aspects

4. Social aspects
Dimensions of

membership involvement:

1. Participation

2. Personal relevance

3. Social world
Outcomes of

membership involvement:

1. Individual outcomes

2. Organizational outcomes

3. Societal outcomes

Figure 3. Framework of membership involvement of members of voluntary sports and active leisure clubs

Table 2. Framework of membership involvement of members of voluntary sports and active leisure clubs

\begin{tabular}{|c|c|c|}
\hline Predictors & Dimensions & Outcomes \\
\hline Personal characteristics & $\begin{array}{l}\text { Participation (sports and non-sports } \\
\text { activity) }\end{array}$ & Individual outcomes \\
\hline $\begin{array}{c}\text { Age and gender } \\
\text { Knowledge } \\
\text { Self-perception (e.g., health, skills and talent) }\end{array}$ & $\begin{array}{l}\text { Duration } \\
\text { Intensity }\end{array}$ & $\begin{array}{c}\text { Health } \\
\text { Skills (sports and non-sports) } \\
\text { Diversion (enjoyment) } \\
\text { Social connectedness }\end{array}$ \\
\hline Psychological aspects & $\begin{array}{c}\text { Personal relevance (individual } \\
\text { psychological) }\end{array}$ & Organizational outcomes \\
\hline $\begin{array}{l}\text { Personal importance } \\
\text { Perceived benefits } \\
\text { Identification } \\
\end{array}$ & $\begin{array}{c}\text { Affective/emotional } \\
\text { Cognitive } \\
\text { Self-expression }\end{array}$ & $\begin{array}{c}\text { Support (e.g., volunteering) } \\
\text { Allegiance }\end{array}$ \\
\hline Organizational aspects & Social world & Societal outcomes \\
\hline $\begin{array}{c}\text { Facilities (service, support) } \\
\text { Accessibility (e.g., financial costs) } \\
\text { Availability of opportunities (role in } \\
\text { organization) }\end{array}$ & $\begin{array}{l}\text { Social interactions } \\
\text { Social relationships } \\
\text { Social networks }\end{array}$ & $\begin{array}{c}\text { Healthy lifestyle (sustained physical } \\
\text { activity) } \\
\text { Learning communities } \\
\text { Social capital }\end{array}$ \\
\hline \multicolumn{3}{|l|}{ Social aspects } \\
\hline $\begin{array}{c}\text { Social background (family, friends and peers) } \\
\text { Social contacts (conversations and meeting } \\
\text { people) } \\
\text { Closeness (with peers, friends or family) }\end{array}$ & & \\
\hline
\end{tabular}




\subsection{Three Dimensions of Membership Involvement}

The findings in the 25 articles reveal the multidimensional nature of membership involvement and the presence of the dimensions participation in activities (i.e., the participation of members in sports and non-sport activities at the club), personal relevance (i.e., the importance of the club to members), and the social world of members at their club (i.e., the contacts and social network of members at the club).

\subsubsection{Participation in Activities}

Six studies conceive involvement as a concept that expresses participation in activities in sports and leisure (8, 12 and 20), or as related to volunteering at a sports club (19), or to other activities (2 and 21). Specific aspects of participation play a role, such as time and frequency $(8,19$, and 20), the experience level (12), the ageing of sport participants (2), or the tenure and intensity of the membership in a sports club or sports program (2 and 21). Because these approaches of involvement incorporate various aspects of participation in activities, the importance of the participation dimension of membership involvement is emphasized.

\subsubsection{Personal Relevance}

The personal relevance of sports or active leisure in organized context has emerged as a dimension of involvement alongside the participation dimension. For example, in a study on youth and sports (1), involvement was considered as participating in sports or physical activities at a voluntary club and the attitude towards the sport activity or sports club. Involvement refers to the extent to which sports and being part of a sports environment (such as a voluntary sports club) has become part of the lifestyle of young people. This attitudinal aspect reflects the personal relevance dimension. In more recent research with students who are voluntary board members at their sports clubs (23), involvement is described as instrumental (participating in activities) and emotional (such as importance, stress, challenge). Finally, aspects of participation and personal relevance are found in a study (10) in which board member involvement is examined in the sense of participation (length of time and number of hours) and effort (extent of dedication to their role) of board members at a sports club.

In other studies involvement is seen as a broad psychological construct with dimensions that reflect the relevance of sports in an organized context. For example, an affective dimension (perceived importance of sports, i.e., interesting, appealing, and exciting) and a cognitive dimension (personal importance of sports, i.e., usefulness, relevance, and importance) were distinguished (3). Other research (9) has approached involvement more as a goal-oriented concept with task involvement (mastering in sports) and ego involvement (competitive behavior). Thus, involvement in this view refers more to a form of self-expression through sport, which underlines the existence of a personal relevance dimension. Noticeable in our analysis were twelve studies that advanced a well-elaborated concept of involvement based on McIntyre and Pigrams' (1992) leisure involvement scales: attraction, centrality, and self-expression. Seven of the studies were limited to these scales $(4,6,11,13,14,15$, and 16$)$. In these studies, 'attraction' (or 'hedonic value') represents aspects of individual enjoyment, in terms of that the pleasurable activity is considered important or meaningful to that individual. An activity is conceived as 'central' if other aspects of an individual's life are organized around that activity, and in which interactions with friends occur, or if the activity has valued life benefits, such as significant health outcomes. Finally, 'self-expression' refers to internally motivated free expression of self (items such as 'When I play sports, I can really be myself') and externally motivated self-representation to others (items such as 'Running says a lot about who I am').

In the other five studies $(5,7,17,18$, and 22) we identified extensions of the McIntyre and Pigrams' (1992) three-fold leisure involvement scales. In two articles (5 and 22), self-expression is elaborated in two identity-representing elements: identity expression (free expression of self) and identity affirmation (self-representation to others). Moreover, all of these five studies incorporate aspects that refer to a 'social world dimension' in the conceptualization of involvement.

\subsubsection{Social World}

The reviewed studies indicate the existence of a 'social world' as the third dimension of involvement. First, three of the studies based on the McIntyre and Pigrams' (1992) leisure involvement scales $(7,17$, and 22) have expanded the scales with elements of social bonding, referring to the ties with family and friends. Furthermore, in one study (5) personal relationships ('social worlds') are found as the most important dimension of enduring involvement. This was drawn from leisure research that relied on Burch (1969), who argued that the social circle that surrounds a participant is crucial to a person's leisure experience and, moreover, bind them to the activity. Moreover, in research into recreational sport (18), the involvement concept is examined with the recreational sport involvement scale developed by Kuo and Yen (2012). These recreational sport involvement scales comprise the social dimension 'impact of friends' and the psychological dimensions 'leisure attraction', 'centrality of life'. Finally, in three articles to participation in sports and leisure activities $(2,19$ and 21), we found elements that refer to social dimensions of membership involvement - in the cases in which a club or program is perceived as an environment where members have social contacts or build social networks. Together, these cases indicate that involvement could be beyond participation in sports and leisure and those members in 
clubs or programs form a social world.

In conclusion, the reviewed studies underpin membership involvement as a concept with a complex nature. While in the earliest studies, MI was mainly related to aspects of participation and personal relevance, over the years studies have identified factors that refer to the importance of a social world within the voluntary clubs. While initially the aspects that we classify as participation and personal relevance were examined as main components, in some studies the aspects that we consider as part of the social dimension were added to existing scales for exploring the social context of the activities, which were often voluntary clubs.

Nevertheless, these findings justify the integration of the social world as a third dimension into our framework of MI of members, alongside participation and personal relevance. This three-dimensional conceptualization of MI shows that to involvement in voluntary clubs, not only the passion to sport is important, but also to the context of the club and its members.

\subsection{Four Groups of Predictors}

In sixteen studies, involvement is examined as the result of one or more factors of various kinds. To understand which driving forces lead to involvement, we classified these factors into four groups of predictors: personal characteristics, individual psychological, organizational and social aspects.

Personal characteristics describe characteristics such as age and gender (2, 4, and 12), but also more complex characteristics that are related to membership involvement, such as beliefs about individual qualities (e.g., skill perception, ability, control, knowledge, individual health and body image in 2, 4, 7, and 12).

Individual psychological aspects provide information about the degree of enthusiasm for a sport or leisure activity, such as personal motivation, perceived benefits e.g., skill acquisition, tension release, feeling younger and healthier $(2,7,11,14,17$, and 22). It is noticeable that in two studies (2 and 12) the ageing of people is related to involvement, which is explained by the perceived (physical) barriers that become more focused while the perceived benefits, such as healthy lifestyle, are less well defined (2), or by aspects that are identified as important, for example the facilities a club offers (12). Interestingly, playing sports video games predicted involvement in organized sports (20).

Organizational aspects refer to service quality such as convenience and staffing responsiveness, reliability, training aids, extra amenities, time-related activities (12 and 15), organizational processes, and the degree of autonomy (9 and 10). Furthermore, 'supporting social interaction' is considered a predictor of involvement (14) in cases where building a 'family atmosphere' supported social interaction and could, subsequently, influence involvement. Finally, financial costs and availability of opportunities are identified as predictors $(17,22$, and 23).

Social aspects include social background, contact and closeness with family, friends, and peers, $(1,2,5,7,14,15$, and 22). These social factors could be positively loaded, such as family sports that contribute to involvement (5), but also more negatively loaded, such as the difficulty of finding a partner for a recreational activity, which is considered a constraint in developing involvement (22). Time spent with friends and family offers value to sports and leisure activities, e.g., as a supportive social environment $(2,4,7$, and 18$)$. For example, in recreational tennis clubs (14), the importance of tennis to the players not only refers to the sport 'tennis' but also to the tennis club where members 'socialize in and outside the club, and of course tennis is a common theme for interaction among members' (p. 66). Moreover, the exchange of information about the sports or club and friendly conversations have been noted as indicators of involvement (11 and 14).

Concluding, the four groups of predictors that emerge from the reviewed articles are lenses that allow us to look at the types of aspects that contribute to membership involvement. The sample of studies show 'neutral' type of predictors (e.g. age, gender, facilities), positively loaded predictors (e.g. enthusiasm, tension release, time spent with friends), and more negatively loaded predictors that function as constraints (e.g. difficulty of finding a partner for a recreational activity). Having a sample of studies across multiple decades, this demonstrates how membership involvement of members can develop and be enhanced.

\subsection{Outcomes for Organizations, Individuals and Society}

In the studies that examine the results of involvement, we have mostly identified positive - and in some cases negative - effects not only for voluntary clubs but for individuals and society as well. On this basis, we uncover three overarching outcome levels: individual, organizational, and societal.

At the individual level, outcomes of involvement in sports and leisure regard personal development, motivations for physical activities, and social connectedness. For example, involvement influences sport-related behavior, such as improved performance in a sports task, or entering a membership of a sports club and, more passively, watching sports on television, playing sports video games or attending a competition in a sports club or sports stadium (3, 9 and 20). Furthermore, in recent studies (21 and 14), we found motivations for physical effort (e.g., diversion and pleasure, reduction of work-related stress, health, and meeting people) emerge as outcomes of involvement, depending on the situation and intensity $(6,18$, and 23) and increased levels of social connectedness ('individual's integration into ones social 
milieu') and interpersonal closeness of members (21 and 14). Moreover, in the most current studies (23, 24, and 25), aspects as study success and developing academic skills emerge as benefits of student's sport involvement. Finally, some negative outcomes are reported in the case where social connectedness at the club was not accompanied by an interest in the club's sports and leisure activities (14) and (8) where involvement in student team sports is connected to substance use (drinking alcohol, smoking marijuana, and chewing tobacco).

At the organizational level, positive outcomes for sports and leisure clubs are described in studies that found that high levels of involvement result in members' increased participation in voluntary work (19) and enhanced performance as board members (10). Furthermore, in a study on running (13), involvement aspects contribute to engagement in running clubs (from low to high engagement: awareness, attraction, attachment, and, mostly, allegiance). In addition, a study into skiing (11) showed positive outcomes where involvement was an indicator of member loyalty.

Finally, at the societal level, we found, for example, that membership involvement contributes to social capital, in terms of social networks in social communities (21), to physical activity, and friendships as indicators of a healthy lifestyle (6), or to healthy working conditions (18). Furthermore, in addition to the results at the individual level, we also see a justification for labelling students' study success as an outcome at the societal level, supported by the assumed impact on, for example, the knowledge-oriented society $(23,24$, and 25$)$. In one study, this was expressed in the concept of the learning community: an environment in which skills and competencies can be developed, such as leadership and organizational skills (23). It is noticeable that especially in studies that are more recent, the relationship with a contribution to society is a recurring subject.

In conclusion, research over the years has shown that involvement not merely contributes to outcomes for voluntary clubs, but also for individuals and society at large. Remarkably, these results are mainly positive, except two findings, that 1) social connectedness is not always paired by an active interest in physical activities and 2) that participation in team sports by students is linked to substance use. These latter findings are of concern to voluntary clubs.

\subsection{Circular Effect}

In addition, based on the sample of studies over the years, the conceptualization of membership involvement not only suggests a mediating but also a circular nature (see Figure 3). More specifically, aspects of the outcomes 'health,' 'skills,' 'diversion,' 'social connectedness,' and 'club support' are similar to aspects of the predictors 'skills-perception,', 'perceived benefits,' 'social contacts,' and 'role in the club.' For example, the outcome 'improvement of personal skills' is comparable to the predictor 'perceived skill acquisition,' which contributes to MI. Furthermore, membership involvement can enhance the feeling of being socially connected, which is similar to the two predictors of MI 'social contacts' and 'closeness.' We did not find this circular effect for all predictors and outcomes, which indicates that not all aspects play the same role in shaping and sustaining membership involvement.

\section{Conclusions and Implications}

The results of our systematic review study reveal that membership involvement of members of voluntary sports and active leisure clubs is a multidimensional concept that mediates a wide range of predictors and outcomes (see Table 2). In contrast to the membership of voluntary clubs, which was once dependent on the social, cultural, or political background of individuals (Breuer et al., 2016; Waardenburg \& Van Bottenburg, 2013), results of our study suggests that membership involvement is nowadays largely linked to individual motivations, health, developing skills, or forming and strengthening one's social network. MI appears to be distinct from other involvement concepts, such as sport involvement or leisure involvement (Funk and James, 2001; McIntyre and Pigram, 1992) because it specifically reflects the importance of the social context (social world) for the members of the voluntary clubs. Moreover, compared with concepts as 'sense of community' or 'social capital,' that refer to the relationships among members (Nielsen et al., 2016; Warner et al., 2012), MI also includes dimensions as 'participation in activities' and 'relevance of the voluntary club to members.' Therefore, the MI-concept provides a more complete understanding of the attachment of members to their club.

The results yield personal, psychological, organizational, and social aspects that predict MI, and these function as lenses that provide insight into ways in which voluntary clubs can develop membership involvement. In contrast to much research in which the underlying aspects of involvement are mostly divided into individual aspects and organizational aspects (cf Engelberg et al., 2011; McIntyre and Pygram, 1992; Van der Roest et al., 2016), we propose a more refined classification of four distinct groups of aspects. As a consequence, the distinction between personal characteristics and psychological aspects allows us to separate individual characteristics, such as age, gender, occupation, and self-image (with regard to health and body image) from personal ideas about what clubs have to offer to their members (e.g., importance, perceived benefits, identification). In doing so, we provide a more detailed understanding of the complexity of how to involve members in voluntary clubs. The results of this systematic 
review indicate multilevel outcomes, in the sense that MI affects not only clubs, but individuals and society as well. This enhances the insight from previous research that revealed that involvement is an important predictor of well-elaborated concepts, such as physical activity in an organized context, organizational commitment, and societal cohesion (Engelberg et al., 2011; Etzioni, 1980; Putnam, 2001; Schlesinger and Nagel, 2015; Van der Roest et al., 2016).

Based on the results of our research we provide a framework with extended outcomes: improvement of skills, health, diversion, and social connectedness at the individual level, support and allegiance at the organizational level, and healthy lifestyle, learning communities, and social capital at the societal level (see Figure 3 and Table 2). These insights illuminate that MI could function as a driving force in these contexts, although we should be careful because some negative effects have also been reported. Therefore, future research should try to obtain a more profound understanding of the effects of membership involvement.

In addition, we suggest that our framework of MI has a circular nature, because some aspects in the selected articles emerge both as outcomes and as predictors - such as health, skills, benefits, social cohesion, and club support. Just this circular nature points to a specific and driving value of membership involvement; it stimulates benefits that, subsequently, enhance membership involvement. Future research should increase our understanding of this circular nature and provide insights into the driving forces of membership involvement for sustainable effects, such as enduring physical activity, loyal membership, building learning communities, and social cohesion.

\subsection{Scientific Implications}

Following the PRISMA guidelines (Moher et al., 2009) and the thematic analysis method (Dixon-Woods et al., 2005; Tranfield et al., 2003), we conducted a systematic review that allows us to identify aspects of involvement and membership through a step-by-step selection of previous articles in relevant databases. To our knowledge, our framework is a first attempt to provide a complete overview of dimensions, predictors and outcomes of membership involvement in the context of sports and active leisure. This first attempt illustrates that this field of membership involvement that defines the emotional attachment of members to their voluntary clubs needs to be elaborated and our systematic review is a step towards a better understanding. Further research, including into the activation of this membership involvement, can be of great importance for the field of voluntary clubs, but also for individuals and the society. This was reflected in the more recent studies in which the concept of involvement related to the individual and to society were recurrent subjects. Grounded in the results of prior studies, our research suggest that MI can have positive outcomes, such as social connectedness, healthy lifestyle, forming of learning communities, and social capital. Future empirical research can help to understand how to foster these benefits and mitigate negative outcomes.

Finally, the studies in this field showed a limited variation in methodological design. Except for a few studies, the lion's share of the studies used a survey design, in which motivation and attitude were evaluated. However, more diversity in research designs could provide a richer picture of membership involvement than has been obtained so far. The conclusions that can be drawn should be carefully interpreted in the light of this limitation of the literature.

\subsection{Implications for Practice}

This framework offers voluntary clubs a wide range of tools for developing membership involvement of their members at four levels: personal characteristics, psychological, organizational, and social. Not only the obvious factors of skills acquisition, or tension release but also perceived benefits (e.g. feeling younger and healthier), playing a role in the organization, creating a social network, or finding partners for a recreational activity and even playing sports video games have emerged as factors in creating membership involvement of members. Furthermore, voluntary clubs may emphasize that MI has positive effects, such as skills achievement (sports and non-sports, e.g. leadership), social connectedness, and a healthy lifestyle. The predictors and outcomes offer voluntary clubs an integrated system for developing membership involvement of their members. The fact that the elements in our framework also form a circular system can benefit both members and voluntary clubs. For example, the development of social aspects enhances the social world within the voluntary clubs, which can lead to more support by its members. Furthermore, the identification with the voluntary clubs contributes to membership involvement on the participation level, with long-term membership as a result. To have a good understanding of these processes, we recommend voluntary clubs to carefully monitor the indicators, such as presented in our framework.

Finally, in contrast to the membership as it once was, the expression of interconnectedness within social groups on the basis of e.g., culture, politics, and religion (Breuer et al., 2016; Waardenburg \& Van Bottenburg, 2013), the results of our study indicate that MI contributes to the development of individual benefits and societal effects, such as healthy lifestyles, learning communities, and social capital. In this respect, the voluntary sports and active leisure clubs appear to be an important arena for achieving individual as well as societal goals. Therefore, it seems worthwhile stimulating MI of members in order to maintain the voluntary clubs as the providers of 
recreational sports and active leisure.

\section{REFERENCES}

[1] Adachi, PJC and Willoughby T (2014). It's Not How Much You Play, but How Much You Enjoy the Game: The Longitudinal Associations Between Adolescents' Self-Esteem and the Frequency Versus Enjoyment of Involvement in Sports. Journal of Youth and Adolescence 43(1): 137-145.

[2] Alexandris K (2012). Exploring the role of motivation on the development of sport involvement. International Journal of Sport Management \& Marketing 12(1/2): 57-72.

[3] Alexandris K. (2013). Segmenting recreational tennis players according to their involvement level: a psychographic profile based on constraints and motivation. Managing Leisure 18(3): 179-193.

[4] Alexandris K, Douka S and Balaska P (2012). Involvement with active leisure participation: does service quality have a role? Managing Leisure 17(1): 54-66.

[5] Alexandris K., Kouthouris C., Funk D, et al. (2008). Examining the Relationships Between Leisure Constraints, Involvement and Attitudinal Loyalty among Greek Recreational Skiers. European Sport Management Quarterly 8(3): 247-264.

[6] Beaton A., Funk D., Ridinger L, et al. (2011). Sport involvement: A conceptual and empirical analysis. Sport Management Review 14(2), 126-140.

[7] Borgers J, Breedveld K, Tiessen-Raaphorst A, et al. (2016). A study on the frequency of participation and time spent on sport in different organisational settings. European Sport Management Quarterly 16(5): 635-654.

[8] Borgers J, Pilgaard M, Vanreusel B, et al. (2018a) Can we consider changes in sports participation as institutional change? A conceptual framework. International review for the sociology of sport 53(1): 84-100.

[9] Borgers J, Vanreusel B, Lefevre J, et al. (2018b). Involvement in non-club organized sport: organizational patterns of sport participation from a longitudinal life course perspective. European Journal for Sport and Society 15(1): 58-77.

[10] Breuer C, Hoekman R, Nagel S, et al. (2016). Sport clubs in Europe: A cross-national comparative perspective. Springer.

[11] Burch WR. (1969). The social circles of leisure: Competing explanations. Journal of Leisure Research 1(2): 125-147.

[12] Darcy S, Maxwell H, Edwards M, et al. (2014). More than a sport and volunteer organisation: Investigating social capital development in a sporting organisation. Sport Management Review 17(4): 395-406.

[13] Dixon-Woods M, Agarwal S, Jones D, et al. (2005). Synthesising qualitative and quantitative evidence: A review of possible methods. Journal of Health Services Research \&
Policy 10(1): 45-53.

[14] Dobersek U and Arellano DL (2017). Investigating the Relationship between Emotional Intelligence, Involvement in Collegiate Sport, and Academic Performance. Sport Journal 20: 1-17.

[15] Eime R, Harvey J, Brown W et al. (2010). Does Sports Club Participation Contribute to Health-Related Quality of Life? Medicine \& Science in Sports \& Exercise 42(5): 1022-1028.

[16] Emrich E, Pitsch W, Flatau J et al. (2014). Voluntary engagement in sports clubs: A behavioral model and some empirical evidence. International Review for the Sociology of Sport 49(2): 227-240.

[17] Engelberg T, Skinner J and Zakus DH (2011). Exploring the relationship between commitment, experience, and self-assessed performance in youth sport organizations. Sport Management Review 14(2): 117-125.

[18] Etzioni, A. (1980). Compliance structures. In Etzioni \& Lehman (Eds.), A sociological reader on complex organizations. 3rd ed. ed., New York [etc.]: Holt, Rinehart and Winston, pp. 87-130).

[19] European Commission. (2014). Sport and physical activity. In European Commission (Ed.), Special Eurobarometer 412. Brussels

[20] Flosdorf ML, Carr BH, Carr JW et al. (2016). An Exploration of the Sport Club President's Experience. Recreational Sports Journal 40(2): 106-119.

[21] Forrester SA, McAllister-Kenny K and Locker M (2018). Association Between Collegiate Recreational Sports Involvement and Undergraduate Student Retention. Recreational Sports Journal 42(1): 1-11.

[22] Funk D and James J (2001). Psychological Continuum Model: A Conceptual Framework for Understanding an Individual's Psychological Connection to Sport. Sport Management Review 4(2): 119-150.

[23] Funk D, Ridinger L and Moorman A (2004). Exploring Origins of Involvement: Understanding the Relationship Between Consumer Motives and Involvement with Professional Sport Teams. Leisure Sciences 26(1): 35-61.

[24] Gahwiler P and Havitz ME (1998). Toward a relational understanding of leisure social worlds, involvement, psychological commitment, and behavioral loyalty. Leisure Sciences 20(1): 1-23.

[25] Geidne S, Quennerstedt M and Eriksson C (2013). The youth sports club as a health-promoting setting: An integrative review of research. Scandinavian Journal of Public Health 41(3): 269-283

[26] Green BC and Chalip L (2004). Paths to volunteer commitment: Lessons from the Sydney Olympic Games. Volunteering as leisure/leisure as volunteering: An international assessment: 49-67.

[27] Hallberg UE and Schaufeli WB (2006). "Same Same" But Different? European Psychologist 11(2): 119-127.

[28] Havitz ME and Dimanche F (1999). Leisure involvement revisited: Drive properties and paradoxes. Journal of Leisure Research 31(2): 122. 
[29] Havitz ME and Mannell RC (2005). Enduring Involvement, Situational Involvement, and Flow in Leisure and Non-leisure Activities. Journal of Leisure Research 37(2): 152-177.

[30] Hoye R (2007). Commitment, involvement and performance of voluntary sport organization board members. European Sport Management Quarterly 7(1): 109-121.

[31] Hoye R, Nicholson M and Brown K (2015). Involvement in sport and social connectedness. International Review for the Sociology of Sport 50(1): 3-21.

[32] Kellett P and Warner S (2011). Creating Communities that Lead to Retention: The Social Worlds and Communities of Umpires. European Sport Management Quarterly 11(5): 23.

[33] Kuo CT (2013). The effect of recreational sport involvement on work stress and quality of life in Central Taiwan. Socia Behavior \& Personality: an international journal 41(10): 1705-1715.

[34] Kyle G, Absher J, Hammit W et al. (2006). An examination of the motivation - involvement relationship. Leisure Sciences 28(5): 467-485.

[35] Kyle G and Chick G (2004). Enduring leisure involvement: The importance of personal relationships. Leisure Studies 23(3): 243-266.

[36] McIntyre N and Pigram JJ (1992). Recreation specialization re-examined: The case of vehicle-based campers. Leisure Sciences 14(1): 3-15.

[37] Moher D, Liberati A, Tetzlaff, J et al. (2009). Preferred Reporting Items for Systematic Reviews and Meta-Analyses: The PRISMA Statement. PLoS Medicine 6(7): e1000097.

[38] Mullen SP and Whaley DE (2010). Age, gender, and fitness club membership: Factors related to initial involvement and sustained participation. International Journal of Sport and Exercise Psychology 8(1): 24-35.

[39] Nielsen G, Grønfeldt V, Toftegaard-Støckel J et al. (2012). Predisposed to participate? The influence of family socio-economic background on children's sports participation and daily amount of physical activity. Sport in Society $15(1): 1-27$.

[40] Penley LE and Gould S (1988). Etzioni's model of organizational involvement: A perspective for understanding commitment to organizations. Journal of Organizational Behavior 9(1): 43-59.

[41] Putnam RD (2001). Bowling alone: The collapse and revival of American community. New York: Touchstone.

[42] Ridinger LL, Funk DC, Jordan JS et al. (2012). Marathons for the Masses: Exploring the Role of Negotiation-Efficacy and Involvement on Running Commitment. Journal of Leisure Research 44(2): 155-178.

[43] Ringuet-Riot C, Cuskelly G, Auld C et al. (2013). Volunteer roles, involvement and commitment in voluntary sport organizations: evidence of core and peripheral volunteers. Sport in Society 17(1): 116-133.

[44] Rockafellow BD and Saules KK (2006). Substance use by college students: The role of intrinsic versus extrinsic motivation for athletic involvement. Psychology of
Addictive Behaviors 20(3): 279-287.

[45] Rudman WJ (1989). Age and Involvement in Sport and Physical Activity. Sociology of Sport Journal 6(3): 228-246.

[46] Sack H-G (1988). The Relationship between Sport Involvement and Life-Style in Youth Cultures. International Review for the Sociology of Sport 23(3): 213-232.

[47] Schlesinger T and Nagel S (2011). "Volunteering in sports clubs as a matter of honor": Analyzing volunteer decisions in sports clubs. Sport und Gesellschaft 8(1): 3-27.

[48] Schlesinger T and Nagel S (2015). Does context matter? Analysing structural and individual factors of member commitment in sport clubs. European Journal for Sport and Society $12(1): 53-78$

[49] Seippel Ø (2006). The meanings of sport: fun, health, beauty or community? Sport in Society, 9(1), 51-70.

[50] Shank M and Beasley F (1998). Fan or fanatic: Refining a measure of sport involvement. Journal of sport behavior 21(4): 435.

[51] Sotiriadou P, Wicker P and Quick S (2014). Attracting and retaining club members in times of changing societies: The case of cycling in Australia. Managing Leisure 19(5): 345-358.

[52] Spray CM, Wang CK, Biddle SJ et al. (2006). Understanding motivation in sport: An experimental test of achievement goal and self- determination theories. European journal of sport science 6(1): 43-51.

[53] Stansfield C, Dickson K and Bangpan M (2016). Exploring issues in the conduct of website searching and other online sources for systematic reviews: how can we be systematic? Systematic Reviews 5: 191.

[54] Thiel A and Mayer J (2008). Characteristics of Voluntary Sports Clubs Management: a Sociological Perspective. European Sport Management Quarterly 9(1): 81-98.

[55] Tranfield D, Denyer D and Smart P (2003). Towards a methodology for developing evidence-informed management knowledge by means of systematic review. British journal of management 14(3): 207-222.

[56] Turner V (1969). Liminality and communitas. The ritual process: Structure and anti-structure 94: 130.

[57] Van Bottenburg, M., Rijnen, B., \& Van Sterkenburg, J. (2005). Sport participation in the EU: Trends and differences. Amsterdam: Mulier Institute.

[58] Van der Roest, J-W, Van Kalmthout J and Meijs L (2016). A consumerist turn in Dutch voluntary sport associations? European Journal for Sport and Society 13(1): 1-18.

[59] Vandermeerschen H, Vos S and Scheerder J (2016). Towards level playing fields? A time trend analysis of young people's participation in club-organised sports. International Review for the Sociology of Sport 51(4): 468-484

[60] Waardenburg, M., \& Van Bottenburg, M. (2013). Sport policy in the Netherlands. International Journal of Sport Policy and Politics, 5(3), 465-475. 
[61] Warner S, Dixon MA and Chalip L (2012). The impact of formal versus informal sport: Mapping the differences in sense of community. Journal of community psychology 40(8): 983-1003.

[62] Weed M (2005). Research Synthesis in Sport Management: Dealing with "Chaos in the Brickyard". European Sport Management Quarterly 5(1): 77-90.

[63] Wiley CGE, Shaw SM and Havitz ME (2000). Men's and Women's Involvement in Sports: An Examination of the Gendered Aspects of Leisure Involvement. Leisure Sciences 22(1): 19-31.

[64] Wood L and Danylchuk K (2011). Playing our way: Contributions of social groups to women's continued participation in golf. Leisure Sciences 33(5): 366-381.

[65] Wood L and Danylchuk K (2015). The impact of constraints and negotiation strategies on involvement in intramural sport. Managing Sport \& Leisure 20(3): 157-173.

[66] Zaichkowsky JL (1985). Measuring the Involvement Construct. Journal of Consumer Research 12(3): 341-352. 